\title{
МАТЕРІАЛОЗНАВСТВО
}

UDC 621.891

DOI: https://doi.org/10.32515/2664-262X.2020.3(34).48-53

Volodymyr Kropivnyi, Prof., PhD in tech. sci., Mykola Bosyi, Sen. Lect., Olexandr Kuzyk, Assoc. Prof., PhD in tech. sci., Alena Kropivna, Assoc. Prof., PhD in tech. sci. Central Ukrainian National Technical University, Kropyvnytskyi, Ukraine e-mail:Kuzykov1985@gmail.com

\section{Specific Distribution of Thermal Effects of Graphite Forming Reactions in High-strength Cast Iron}

The dependence of thermal effects of reactions in the formation of inclusions of vermicular and globular graphite is substantiated in the article. The calculation of thermal effects according to the heat of formation of reagents in cast iron and their dependence on the temperature factor is given. The distribution of temperatures and carbon content in the eutectic shell is shown, increasing the compact inclusion of graphite due to diffusing carbon from the melt through the austenitic shell.

high-strength cast iron, globular graphite, vermicular graphite, crystallization, thermal effect of reactions

В.Н. Кропивный, проф., канд. техн. наук, Н.В. Босый, ст.препод., А.В. Кузык, доц., канд. техн. наук, А.В. Кропивная, доц., канд. техн. наук

Центральноукраинский национальный технический университет г. Кропивницкий, Украина

Особености распределения тепловых эффектов реакций формирования графита высокопрочных чугунов

В статье приведен расчет тепловых эффектов с теплотой образования реагентов в чугуне и установлено их зависимость от температурного фактора. Обоснована роль теплофизических процессов в формировании включений вермикулярного и шаровидного графита, с обеспечением их роста за счет диффузии углерода из расплава через аустенитную оболочку.

высопрочный чугун, шаровидный графит, вермикулярный графит, кристаллизация, тепловой эфект реакций

Statement of the problem. High-strength cast irons continue to keep a leading position amongst structural materials in modern engineering. This group of cast irons is characterized by high strength and durability indicators at the level of carbon steels with high level of foundry properties (liquidity, segregation). All the facts show the increase of demand for the use of high-strength cast iron for the manufacture of machine parts and mechanisms. Modern technologies applied in the production of high-strength cast iron make it possible to obtain a set of enhanced properties, which are achieved by modifying the melts with spheroidizing elements and forming graphite inclusions of compact form, as well as alloying. At the same time, the issues of the mechanism of forming globular graphite are still debatable and do not allow reaching a generally accepted theoretical explanation of the phenomena.

It is known that cast iron has thermophysical characteristics, which strongly depend on the nature of the forming structure, the parameters of which depend on local crystallization conditions. Physicochemical processes occurring during crystallization of high-strength cast iron complicate the explanation of the mechanism of formation of inclusions of spherical and compact forms of graphite. The varied hypotheses of the formation of globular graphite and current possibilities of computer simulation do not lead to a generalized theoretical explanation of the phenomena that occur during graphitization. The discovery of the

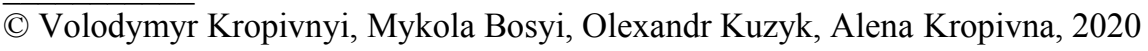


mechanism of the processes of formation of globular graphite will open possibilities for controlling the structure and properties of high-strength cast iron. That allows developing effective technological processes for obtaining cast products for various purposes.

Analysis of recent research and publications. Modern research methods create new opportunities to confirm or disprove the validity of one or another hypothesis about the formation mechanism of globular and vermicular graphite in high-strength cast iron.

There is a number of works [2] in which the formation of globular graphite (after modifying the melt with magnesium-containing additives) is associated with "gas bubbles" of magnesium vapour. However, such hypotheses do not explain the formation mechanism of vermicular graphite inclusions in magnesium iron. Attempts are made to transform the bubble theory with new experimental data, for example, the discovery of new modification of carbon - fullerenes and their detection in iron-carbon alloys [3].

Studies on the formation of graphite nucleus [11-13] show that the centre of the graphite globule contains $\mathrm{Ca}, \mathrm{Mg}, \mathrm{S}, \mathrm{Si}$, and $\mathrm{O}$, therefore, calcium and magnesium sulphides $(\mathrm{CaS}, \mathrm{MgS})$ are surrounded by an oxide layer and are considered as substrates for graphite nucleation. With the increase of magnesium in the melt, the number of magnesium-containing compounds increases and they affect the formation of the microstructure of the matrix, graphite and inter-granular boundary. Growth of graphite globules, their size and shape are determined by such factors as: the nature of the nucleus; the ability of the nucleus to adsorb impurities and gases and the rate of carbon diffusion.

The authors in the work [7] associate the formation of a globular graphite form with the purification of the melt from surfactants of sulphur, oxygen and other impurities. As a result of this cleaning, the ratio of surface tension on the interface surfaces between the melt and the base and prismatic planes of graphite inclusions changes. This theory allows explaining the difference in the formation of globular and vermicular graphite, but does not explain a number of issues. They are the correlation between the refining and spheroidizing action of chemical elements, the influence of the rate of crystallization of the melt on the formation of graphite.

A number of researchers [8,9] associated the formation of compact forms of graphite with their growth in the process of eutectic crystallization due to the diffusion of carbon through the austenitic shell. The calculations confirmed the sufficiency of the eutectic crystallization time of the modified melt for the growth of compact inclusions due to carbon diffusion through the austenitic phase. It is noted that the conditions of heat transfer from the surfaces at the crystallization fronts on which exothermic reactions occur: crystallization of austenite and separation of graphite out of a liquid or solid carbon solution in iron, play a significant role in the processes of graphite formation during the crystallization of cast iron. The results of computer simulations indicate that these thermal effects can have a significant impact on the development of diffusion and liquidation processes.

Statement of the objective. Thus, the purpose of this work is to clarify the role of thermal effects of reactions in the process of crystallization of austenite and the formation of graphite inclusions in modified high-strength cast iron.

Main material. The studies were carried out on samples of high-strength cast iron, which was smelted in an induction furnace, the chemical composition of which corresponded to the BY 500-2 brand (DSTU 3925-99). The melt was modified in the ladle by sandwich method to $\mathrm{Mg}_{\text {residual portion }}=0.035 \%$ by VL $63(\mathrm{O})$ ligature with $\mathrm{Mg}=6.3 \%, \mathrm{Ca}=1.8 \%$, $\mathrm{Si}=46 \%, \mathrm{Fe}-$ the rest.

Slides preparations were carried out according to conventional methods. Metallographic analysis was performed using a MIM-7 microscope.

In the first phase of the study, the modified cast iron was poured into graphite crucibles with the capacity of $1 \mathrm{~kg}$ and $5 \mathrm{~kg}$. After a period of time which is sufficient for the formation of crust up to $10 \mathrm{~mm}$ thick on the surface of the crucible, the non-crystallized liquid 
residue in the centre of the crucible was poured out and subsequent rapid cooling of the crystallized crust with aqueous brine was carried out. Microstructure studies have shown that the placed inclusions of globular graphite, even directly near the inner surface of the crust are surrounded by a ferrite shell. Inclusions of vermicular graphite come to the surface of the section with the ends surrounded by ferrite only on the sides. This indicates that the ends of the inclusions of compact and vermicular graphite in some periods of the crystallization process had contact with the melt. At the same time, it is noted that hardened specimens in the end region, the inclusions of vermicular graphite have a significantly smaller thickness (up to 3 microns), compared to the thickness of the inclusions in the zones that are farther from the crystallization front. This indicates a significant role in further formation of the diffusion growth of inclusions of compact graphite through the austenitic shell. Thus, after the formation of the nucleus of globular graphite, it is completely surrounded by its austenitic shell, and when forming vermicular graphite it is only partial.

According to the method of calculation of thermal effects of reactions on the heat of the formation of reagents in cast iron, on the basis of the initial data given in [10], a thermodynamic calculation of thermal effects of reactions was carried out:

$$
\mathrm{Fe}_{\mathrm{p}} \rightarrow \mathrm{Fe}_{\mathrm{Tв}} ;[\mathrm{C}]_{\mathrm{Fe}} \rightarrow \mathrm{C} г \mathrm{p} ;[\mathrm{C}]_{\mathrm{Fe}} \rightarrow \mathrm{Fe}_{3} \mathrm{C} \text {. }
$$

The calculations of thermal effects of the given reactions in the cast iron were cariied out by the formula:

$$
C_{p}=a+b \cdot 10^{-3} T+c \cdot 10^{5} T^{-2} \text { Дж/моль } \cdot \mathrm{K}
$$

The change of enthalpy was defined $\Delta H_{298}^{0}$ :

- for the reaction $\mathrm{Fe}_{\mathrm{p}} \rightarrow \mathrm{Fe}_{\mathrm{Tв}}: \Delta H_{298}^{0}=\Delta H_{\mathrm{Fe}_{\mathrm{Tв}}}^{0}-3 \Delta H_{\mathrm{Fe}_{\mathrm{p}}}^{0}=0$;

- for the reaction [C]Fe $\rightarrow$ Сгр: $\Delta H_{298}^{0}=\Delta H_{\mathrm{C}_{г \mathrm{p}}}^{0}-\Delta H_{[\mathrm{C}]_{\mathrm{Fe}}}^{0}=0$;

- for the reaction $[\mathrm{C}] \mathrm{Fe} \rightarrow \mathrm{Fe}_{3} \mathrm{C}: \Delta H_{298}^{0}=\Delta H_{\mathrm{Fe}_{3} \mathrm{C}}^{0}-\Delta H_{[C]_{\mathrm{Fe}}}^{0}=22,61 \mathrm{~kJ} / \mathrm{mole}$.

The coefficients of temperature dependency of the change of heating capacity $\Delta C_{P}$ in the process of reaction $\mathrm{Fe}_{\mathrm{p}} \rightarrow \mathrm{Fe}_{\mathrm{B}}$ were:

$$
\Delta a=14,11-41,87=-27,76 ; \Delta b=29,27-0=29,27 ; \Delta c=1,80-0=1,80 .
$$

And the change of heating capacity of $\Delta C_{p}$ system, as a result of the reaction $\mathrm{Fe}_{\mathrm{p}} \rightarrow \mathrm{Fe}_{\text {тв }}$ was:

$$
\Delta C_{p}=-27,76+29,27 \cdot 10^{-3} T+1,80 \cdot 10^{5} T^{-2} \mathrm{~J} / \mathrm{mole} \cdot \mathrm{K} \text {. }
$$

The coefficients of temperature dependency of the change of heating capacity in the process of reaction $[\mathrm{C}] \mathrm{Fe} \rightarrow \mathrm{C} г \mathrm{p}$ were:

$$
\Delta a=16,75-0=16,75 ; \Delta b=4,27-0=4,27 ; \Delta c=-8,37-0=-8,37 .
$$

Heating capacity change of $\Delta C_{p}$ system as a result of reaction [C]Fe $\rightarrow$ Сгр was defined by the ratio:

$$
\Delta C_{p}=16,75+4,27 \cdot 10^{-3} T+(-8,37) \cdot 10^{5} T^{-2} \mathrm{~J} / \mathrm{mole} \cdot \mathrm{K} .
$$

For the reaction $[\mathrm{C}]_{\mathrm{Fe}} \rightarrow \mathrm{Fe}_{3} \mathrm{C}$ the calculated coefficients of temperature dependency of the change of heating capacity were:

$$
\Delta a=82,23-0=82,23 ; \Delta b=83,73-0=83,73 ; \Delta c=0-0=0 .
$$

The change of heating capacity of $\Delta C_{p}$ system of the reaction [C]Fe $\rightarrow \mathrm{Fe}_{3} \mathrm{C}$ :

$$
\Delta C_{p}=82,23+83,73 \cdot 10^{-3} T+0 \cdot 10^{5} T^{-2} \mathrm{~J} / \mathrm{mole} \cdot \mathrm{K} .
$$

Calculated heating effect $\Delta \mathrm{H}_{\mathrm{T}}^{0}$ of the reaction $\mathrm{Fe}_{\mathrm{p}} \rightarrow \mathrm{Fe}_{\text {тв }}$ for the temperature interval $1103 \ldots 1401^{\circ} \mathrm{C}$ was $\Delta \mathrm{H}^{0}{ }_{\left(1103^{\circ} \mathrm{C}\right)}=43,368 \mathrm{~kJ} /$ mole

Similarly, heating effects for the reaction $[\mathrm{C}]_{\mathrm{Fe}} \rightarrow \mathrm{C} \Gamma \mathrm{p}$ were defined in the temperature interval $1152 \ldots 1348^{\circ} \mathrm{C}$ and for the reaction $[\mathrm{C}]_{\mathrm{Fe}} \rightarrow \mathrm{Fe}_{3} \mathrm{C}$ in the temperature interval $1170 \ldots 1374^{\circ} \mathrm{C}$. The results of the assessment of heating effects of the reactions are shown in 
fig. 1 in the form of histogram.

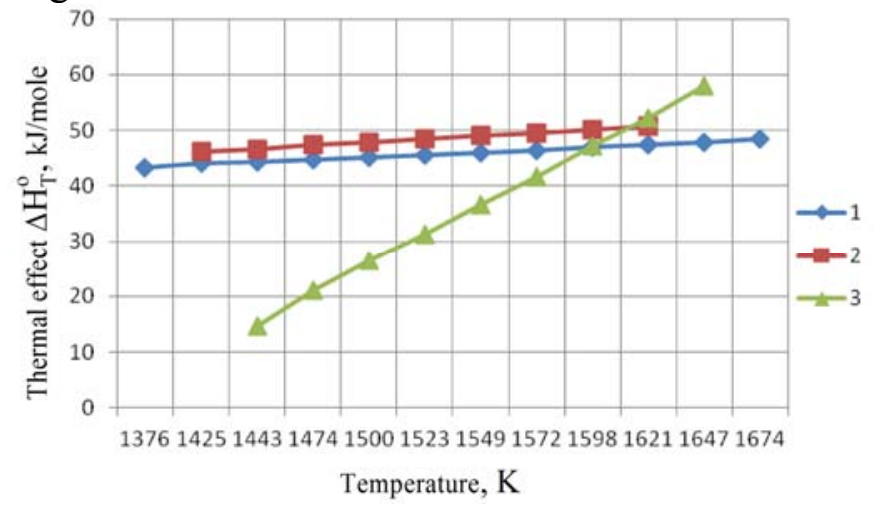

1 - reaction $\mathrm{Fe}_{\mathrm{p}} \rightarrow \mathrm{Fe}_{\mathrm{TB}} ; 2$ - reaction $[\mathrm{C}]_{\mathrm{Fe}} \rightarrow \mathrm{C} \Gamma \mathrm{p} ; 3$ - reaction $[\mathrm{C}]_{\mathrm{Fe}} \rightarrow \mathrm{Fe}_{3} \mathrm{C}$

Figure 1 - Dependency of thermal effects of reactions on temperature factor

Source: developed by the author

Mole particles (content) of $\mathrm{Fe}$ and $\mathrm{C}$ in cast iron equal $96 \%$ and $4 \%$ respectively:

$m_{(\mathrm{Fe})}=m($ cast iron $) \cdot m$ particle $(\mathrm{Fe})=100 \cdot 0,96=96 \Gamma ; m_{(\mathrm{C})}=m$ (cast iron) $\cdot m$ particle (C) $=100 \cdot 0,04=4 \mathrm{~g}$

Molar mass of Fe and $\mathrm{C}$ are: $M_{(\mathrm{Fe})}=56 \mathrm{~g} / \mathrm{mole} ; M_{(\mathrm{C})}=12 \mathrm{~g} / \mathrm{mole}$.

The quantity of $\mathrm{Fe}$ and $\mathrm{C}$ in $(100 \mathrm{~g})$ cast iron, that is their molar particle are:

$n_{(\mathrm{Fe})}=\frac{m_{\mathrm{Fe}}}{M_{(\mathrm{Fe})}}=\frac{96 \mathrm{~g}}{56 \mathrm{~g} / \text { mole }}=1,714$ mole $; n_{(\mathrm{C})}=\frac{m_{\mathrm{C}}}{M_{(\mathrm{C})}}=\frac{4 \mathrm{~g}}{12 \mathrm{~g} / \text { mole }}=0,333$ mole.

The amount of heat released during the crystallization of the austenitic phase along the boundary of the melt-austenite separation is $76.69 \mathrm{~kJ}$ per $1 \mathrm{~kg}$ of melt. Accordingly, the amount of heat released on the austenite-compact graphite inclusion boundary is $15.39 \mathrm{~kJ}$ per $1 \mathrm{~kg}$ of melt. This nature of the distribution of heat release areas determines that the surrounding inclusion of compact graphite is the solid austenitic phase and it will have a substantially higher temperature than the surrounding melt (Fig. 2).

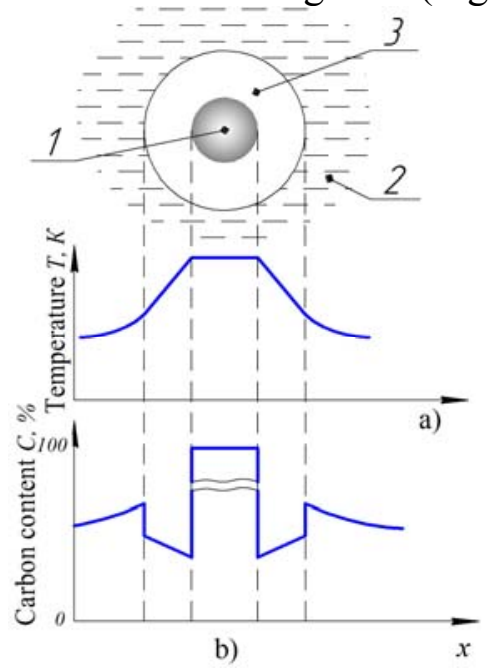

1 - graphite; 2 - melt; 3 - austenite shell

Figure 2 - Temperature distribution a) and carbon content $b$ ) in austenite shell

Source: developed by the author

of growing compact inclusion of graphite

The existence of a continuous overheated austenitic shell is possible due to the reduced carbon content and, consequently, an increase in the solidus temperature. In its turn, it creates the conditions for the intense diffusion of carbon through austenite from the melt of the eutectic composition to the surface of graphite inclusions. Special thermophysical conditions of 
formation of austenitic shells lead to high content of silicon and reduced manganese, which results in the formation of ferrite shells around the inclusions of compact graphite.

\section{Conclusions.}

1. The calculation of thermal effects according to the heat of the formation of reagents in cast iron was carried out and their dependence on the temperature factor was established.

2. The role of thermophysical processes in the formation of inclusions of vermicular and globular graphite with their growth due to the diffusion of carbon from the melt through the austenitic shell has been experimentally and theoretically substantiated.

\section{Список літератури}

1. Гнатуш В.А., Дорошенко В.С. Состояние и перспективы развития мирового рынка литья из чугуна с шаровидным графитом . Литье Украиныл. 2017. №2 (198). С. 24-33.

2. Савуляк В. І., Янченко О.Б. Економічні технології високоміцних графітизованих сплавів заліза: монографія. Вінниця: ВНТУ, 2014. 160 с.

3. Центры кристаллизации графита в серых чугунах / И. Рипоза, М. Чизамера, Т. Скаланд, М. И. Онсойен. Elkem ASA, Foundry Products, 2006. C. 24-37.

4. Корович В.А., Палавин Р.Н. Комплексная обработка расплава стали и чугуна: монографія. Нижний Новгород: Нижнегород. гос. техн. ун-т им. Р. Е. Алексеева, 2009. 101с.

5. Кульбовский И.К. Поддубный А. Н., Богданов Р. А. Получение чугуна с шаровидным и вермикулярным графитом без применения магнийсодержащих модификаторов. Литейное производство. 2007. № 2. С. 7-9.

6. Аулін, В. В., Кропівний В. М., Кузик О. В. З'ясування природи процесів структурних та фазових перетворень в залізовуглецевих сплавах на основі утворення молекулярної форми вуглецю. Техніка в сільськогосподарському виробництві, галузеве машинобудування, автоматизація: зб. наук. пр. Кіровогр. наи. техн. ун-ту. 2016. Вип. 29. С. 94-104.

7. Мильман Б.С. Осада Н.Г., Ильичева Л.В. Основные факторы образования шаровидного графита в чугуне. Основы образования литейных сплавов. Москва: Наука, 1970.

8. Комаров О.С. Формирование структуры чугунных отливок. Мн.: Наука и техника, 1977. 224 с.

9. Toshiro Owadano, Koji Yamada, Kiyoshi Torogoe. Quantitative Metallographic Study of the Solidification of Spheroidal Graphite Cast Iron. Trans. JIM. Vol.18, 1977, p.871-877.

10. Сабірзянов Т.Г., Кропівний В.М. Теплотехніка ливарних процесів. Кіровоград: КНТУ, 2005. 403 c.

11. Зенкин Р.Н. Механизм кристаллизации высокопрочного чугуна. Технические науки: известия ТулГУ. 2013. № 6, ч. 1. С. 192-200.

12. Панов, А.Г. Влияние микроструктуры ФСМг-модификаторов на кристал-лизацию и микроструктуру высокопрочных чугунов. Металлургия $u$ материаловедение: труды Нижегородского гос. техн. ун-та им. Р.Е. Алексеева. 2013. № 1 (98). С. 209-219.

13. Effect of mould inoculation on formation of chunky graphite in heavy section spheroidal graphite cast iron parts / I. Asenjo, P. Larranaga, J. Sertucha, R. Suarez, J.-M. Gomez, I. Ferrer, J. Lacaze. International journal of cast metals research. 2007. Vol. 6. № 6. P. 319-324.

\section{References}

1. Gnatush, V.A. \& Doroshenko, V.S. (2017). Sostojanie i perspektivy razvitija mirovogo rynka lit'ja iz chuguna s sharovidnym grafitom [State and prospects of development of the global cast iron graphite casting market Casting of Ukraine]. Lit'e Ukrainy - Casting Ukraine, 2 (198), 24-33 [in Russian].

2. Savuliak, V.I. \& Yanchenko, O.B. (2014). Ekonomichni tekhnolohii vysokomitsnykh hrafityzovanykh splaviv zaliza [Economic technologies of high-strength graphitized iron alloys]. Vinnytsia: VNTU [in Ukrainian].

3. Ripozan, I., Chizamer, M., Skaland, T. \& Onsoyen, M. I. (2006). Centry kristallizacii grafita v seryh chugunah [Centres for crystallization of graphite in gray cast iron]. Elkem ASA, Foundry Products [in Russian].

4. Korovich, V.A. \& Palavin, R. N. (2009). Kompleksnaja obrabotka rasplava stali i chuguna [Complex treatment of steel and cast iron melt]. Nizhny Novgorod.: Nizhny Novgorod. R.E. Alekseev State tech. university [in Russian].

5. Kulbovskiy, I.K., Poddubnyi, A.N. \& Bogdanov, R.A. (2007). Poluchenie chuguna s sharovidnym i vermikuljarnym grafitom bez primenenija magnijsoderzhashhih modifikatorov [Production of cast iron with globular and vermicular graphite without the use of magnesium-containing modifiers]. Litejnoe proizvodstvo - Foundry production, 2, 7-9 [in Russian].

6. Aulin, V.V., Kropivnyi, V.M., \& Kuzyk O.V. (2016). Z'iasuvannia pryrody protsesiv strukturnykh ta fazovykh peretvoren' $\mathrm{v}$ zalizovuhletsevykh splavakh na osnovi utvorennia molekuliarnoi formy 
vuhletsiu [The elucidation of the nature of the processes of structural and phase transformations in ironcarbon alloys on the basis of the formation of the molecular form of carbon]. Tekhnika $v$ sil's'kohospodars'komu vyrobnytstvi, haluzeve mashynobuduvannia, avtomatyzatsiia: zb. nauk. pr. Kirovohr. nats. tekhn. un-tu. - Collection of Scientific Works of KNTU. Engineering in agricultural production, industrial engineering, automation, Vol. 29, 94-104 [in Ukrainian].

7. Milman, B.S., Osada, N.G. \& Ilyicheva L.V. (1970). Osnovnye faktory obrazovanija sharovidnogo grafita $v$ chugune [Main factors of the formation of globular graphite in cast iron]. Fundamentals of the formation of cast alloys. Moskow: Scienc. [in Russian].

8. Komarov, O.S. (1977). Formirovanie struktury chugunnyh otlivok [Formation of the structure of cast iron castings]. Mn.: Science and technology [in Russian].

9. Toshiro Owadano, Koji Yamada, Kiyoshi Torogoe (1977). Quantitative Metallographic Study of the Solidification of Spheroidal Graphite Cast Iron (Trans. LM.), Vol.18. 871-877.

10. Sabirzyanov, T.G. \& Kropivnyi, V.M. (2005). Teplotekhnika lyvarnykh protsesiv [Heat engineering of casting processes]. Kirovohrad: KNTU [in Ukrainian].

11. Zenkin, R.N. (2013). Mehanizm kristallizacii vysokoprochnogo chuguna [The crystallization mechanism of ductile iron]. Tehnicheskie nauki: izvestija TulGU - Bulletin of the TulSU. Technical science. No. 6, 1, 192-200 [in Russian].

12. Panov, A.G. (2013). Vlijanie mikrostruktury FSMg-modifikatorov na kristal-lizaciju i mikrostrukturu vysokoprochnyh chugunov [The influence of the microstructure of FSMg-modifiers on the crystallization and microstructure of high-strength cast irons]. Metallurgija i materialovedenie: trudy Nizhegorodskogo gos. tehn. un-ta im. R.E. Alekseeva - Proceedings of Nizhniy Novgorod State Technical University named after R.E. Alekseev. Metallurgy and materials science. No. 1, 98, 209-219 [in Russian].

13. I. Asenjo et al. (2007). Effect of mould inoculation on formation of chunky graphite in heavy section spheroidal graphite cast iron parts. International journal of cast metals research, Vol. 6, 6, 319-324 [in English.

В.М. Кропівний, проф., канд. техн. наук, М.В. Босий, ст. викл., О.В. Кузик, доц., канд. техн. наук,

А.В. Кропівна, доц., канд. техн. наук

Центральноукраӥнський національний технічний університет, м. Кропивницький, Украйна

\section{Особливості розподілу теплових ефектів реакцій формування графіту у високоміцних чавунах}

Питання механізму формування кулястого графіту все ще залишаються дискусійним та не дає досягнути загальноприйнятного теоретичного пояснення протікаючих явищ. Розкриття механізму процесів формування кулястого графіту сприятиме відкриттю широких можливостей управління структурою і властивостями високоміцного чавуну. Таким чином, метою даної роботи $\epsilon$ уточнення ролі теплових ефектів реакцій в процесі кристалізації аустеніту і формуванні включень графітну у модифікованому високоміцному чавуні.

Дослідження мікроструктури показало, що розміщенні включення кулястого графіту навіть безпосередньо біля внутрішньої поверхні кірки знаходяться в оточенні феритної оболонки. Включення вермикулярного графіту виходять на поверхню розділу торцями, які оточені феритом лише по бокам. Це свідчить, що торці включень компактного та вермикулярного графіту в окремі періоди процесу кристалізації мали контакт з розплавом. Таким чином, після формування зародка кулястого графіту відбувається повне оточення його аустенітною оболонкою, а при формуванні вермикулярного графіту лише часткове. Згідно з методикою розрахунку теплових ефектів реакцій за теплотою утворення реагентів в чавуні, кількість теплоти, яка виділяється при кристалізації аустенітної фази по межі поділу "розплав - аустеніт" становить 76,69 кДж на 1кг розплаву. Відповідно, кількість тепла, яке виділяється на межі "аустеніт - компактне графітне включення" складає 15,39 кДж на 1 кг розплаву. Тобто, оточуюча включення компактного графіту тверда аустенітна фаза буде мати суттєво вищу температуру ніж оточуючий іiі розплав. Особливі теплофізичні умови формування аустенітних оболонок приводить до підвищеного вмісту у них кремнію та пониженого марганцю, наслідком чого є формування феритних оболонок навколо включень компактного графіту.

Обгрунтовано залежність теплових ефектів реакцій у формуванні включень вермикулярного та кулястого графіту. Наведено розрахунок теплових ефектів за теплотою утворення реагентів в чавуні та встановлено їх залежність від температурного фактору. Показано розподіл температур та вмісту вуглецю в евтектичній оболонці, ростучого компактного включення графіту за рахунок дифузії вуглецю 3 розплаву через аустенітну оболонку.

високоміцний чавун, кулястий графіт, вермикулярний графіт, кристалізація, тепловий ефект реакцій 